\title{
THE WAR AGAINST ISLAM AND THE MUSLIMS AT HOME: THE MUDEJAR PREDICAMENT IN THE KINGDOM OF VALENCIA DURING THE REIGN OF FERNANDO «EL CATÓLICO»
}

Por

MARK D. MEYERSON

Fernando's internal policy of fostering the communities of Muslims, or Mudejars, in the territories of his own Crown of Aragon seems at odds with a foreign policy which involved crusades against the Islamic states of Granada and the Maghrib, and encounters with the Ottoman Turks further east. This contradiction can be explained partly by the union of two Crowns with somewhat divergent interests. Whereas Isabel's Castile supplied the impetus and the majority of the manpower for the crusades, still vital in Aragon were the habits of Mediterranean frontier life, which admitted the necessity of minority enclaves and impelled Catalan and Valencian toward the Maghrib and Granada for commerce (1). Nevertheless, as he engaged in a protracted struggle with Islam, Fernando was not blind to the potential Muslim menace at home, particularly in the kingdom of Valencia, where the Mudejars comprised roughly thirty per cent of the population. There, the history of Mudejar rebellion and ambivalent loyalty to the Crown afforded the king little cause for comfort (2). Moreover, earlier anti-Muslim violence on the part of Christians suspicious of Mudejar intentions suggested a possible threat to the public order (3). As recent as 1455, the morería of the city of Valen-

11) Discussions of Fernando's foreign policy have not given enough attention to his internal policy as an indication of his motives and priorities. The view that Fernando was motivated solely by a desire to crusade against Islam, presented by jOSE M. DOUSSINAGUE, La politica internacional de Fernanda el Catolico (Madrid, 1944), does not jibe with Fernando's consistent encouragement of Mudejarism in the lands of the crown of Aragon. J. N. HILLGARTH, The Spanish Kingdoms, $\checkmark$. If loxford, 19781 . pp. 534-584, presents a more balanced view of Fernando's Mediterranean policy, in which confron. tation with islamic powers and the furthering of Aragon's Mediterranean interests often coincide.

(2) ROBERT IGNATIUS BURNS, Islam Under the Crusaders (Princeton, 1974), pp. 37-45, discusses thirteenth century Mudejar revolts; and JOHN BOSWELL, The Royal Treasure (New Haven, 1977), pp. 372-400, treats Mudejar rebellion and defection during the mid-fourteenth certury wars with Castile.

(3) ROBERT IGNATIUS BURNS, "Social Riots or the Christians-Moslem Frontier: Thirteenth Century Valencia", American Historical Review, 66 (1969), pp. 378-400; and MIGUEL GUAL CAMARENA, "Los mudejares valencianos en la epoca del Magnánimow, $N$ Congreso de Historia de la Corona de Aragón, 1 (1959), pp. 473-474, list instances of Christian violence in the fourteenth and fifteenth centuries. 
cia had been assaulted by mobs distressed by severe economic hardship and fearful of a rumored Nașrid offensive with an attendant Mudejar rising (4).

In this paper we will discuss how conflicts with specific Muslim foes affected Fernando's perception of and policy toward his Muslim subjects in the kingdom of Valencia, and how the Mudejars themselves responded to the intensification of the perennial confrontation between Christianity and Islam.

Of the Islamic powers which Fernando had to face, the expanding empire of the Ottoman Turks posed the greatest threat. The danger peaked in August, 1480, when the forces of Mehmet the Conqueror captured Otranto on the Italian mainland, possibly as a prelude to the conquest of Sicily, an Aragonese possession, and of Rome itself. The crisis passed when the death of Mehmet compelled a Turkish withdrawal from Otranto in September, 1481.

During these critical months, Spain's ascendancy over Islam in the west suddenly seemed precarious. Turkish advances rendered the sultanate of Granada more formidable and the allegiance of Fernando's Muslim subjects more uncertain. Fernando was anxious about the possibility of a Mudejar reaction in Valencia to Ottoman successes. In December, 1480, he reminded his officials of the Turks' entry into Italy and then, noting Valencia's proximity to Granada, fretted over the fact that his kingdom had such a large number of Muslim inhabitants who were well armed and had access to its castles. Having had to postpone the crusade against Granada to counter the Turkish menace, Fernando determined at least to neutralize the Mudejars, lest they should «...make some effort in our disservice and of our Lord God and in damage of that kingdom». He ordered that all Muslims in the kingdom be disarmed and denied access to or custodianship of castles, so that "...we may be without any fear of the said Moors (5)".

However, Fernando added that his officials should act as they deemed best, with out causing any "... inconvenience or scandal $(6) \mathrm{m}$. In effect, this meant that they could do very little. Although arms control could be exercised in royal cities and towns (7), seigneurial opposition made it unfeasible in the baronies where the majority of Muslims resided (8). Indeed, documents from 1487 and 1502 describe the Mudejars as still armed to the teeth (9). Lacking evidence of Mudejar activity suggesting insurrec-

(4) GUAL, "Mudélares", pp. 472-494, gives an account of the attack and notes that, a few days after, the cry amoros venen!" sent armed men scrambling to the city's walls. JOSE HINOJOSA MONTALVO "Las relaciones entre los reinos de Valencia y Granada durante la primera mitad del sigio XV", in Estudios de Historia de Valencia (Valencia, 1978), pp. 101-103 sees the assault on Valencia's moreria in 1455 as resulting from the fear of a rumored Naşrid offensive, and notes that the jurats of Valencia described the Mudejars as unostres enemichs publichs".

(5) ACA: C 3605. 87r (13 December, 1480): "... no ignoran la entrada del Turch en la ltalia per la qual cosa ab diligencia e gran sollicitud se de[ve]n entendre en fer los provisons degudes per forma que en nostres regnes e terres per negligentia e no cura se seguis algun inconvenient e perque vosaltres no ignoran aquex nostre Regne de Valencia quanta vicinitat te al Granada y quant gran nombre de moros hi habiten los quals segons soms informats tenen moltes armes e tenen entrada y participi en alguns castefls e fortalezes. E porias sdevenir que ab aquestes novitats del Turch fessen qualque assaig en deservey de nostre Senyor Deu e nostre e dan de aqueix Regne. Per ço... havem deliberat que vosaltres pensen per quina via millor o pus tanta e comoda sense inconvenient o scandel algu se poran levar totes les armes als mors habitants en aqueix Regne axi en ciutats viles e lochs nostres com de barons e de ecclesiastichs. E que sia prohibit als dits moros entrar en fortalezes... E si alguns moros tenen alcaydies de alguns castells que sia provehit que aquells los sien llevades per forma que sense recel algu dels dits moros puixam star...

(6) ACA: C 3605: 87r.

17) ARV: B 1156: 874r-v 112 October, 1480), and ARV: B 1157: 265v-266r (27 June, 1482), are examples of licenses for bearing arms granted to Muslims. ARV: B 1160: 270r (16. August, 1491): the justice of Onda confiscates Muslim's arms

(8) AMV: $\mathrm{g}^{3}$ 29: $247 \mathrm{v}-248 \mathrm{r}$ (15 February, 14811. While informing Fernando of their own concern about the Mudejars' intentions in the wake of Turkish successes, the jurats of Valencia noted that the seigneurs would prefer to maintain the astatus quon instead of taking action against the Mudejars: "E iatsia que los qui tenen heretats poblades de moros volrien ques lexas a benefici de natura empero axi per... benefici del dit Regne de Valentia es milor proveyrhi perque lo dit vostre Regne sia preservat de irreparable ruynan.

(9) ACA: C 3665: 72, (23 April, 1487): 4...cascun moro segons se diu te en sa casa armes sobrades moltes mes de les que cascu dells ha mester". ARV: C 650: 242r-243v 112 April, 1502). 
tion, royal officials kept only a cautious eye on the Moors without unnecessarily upsetting them by the application of a firm hand.

The Turks continued to preoccupy Fernando throughout the 1480s, and, so long as Islam was politically alive in Granada, the Mudejars remained a related, though by no means constant, concern. In 1487 Fernando received disturbing information that the Mudejars had dispatched two envoys to "the Turk", Bayezit II, to inform him of Spain's war against Granada and to request support for the Nașrids before all was lost. The envoys had suggested that Bayezit send his soldiers to Valencia, and there, as in the other Spanish kingdoms, 200,000 Muslims would rise up in their favor and bring about the "...damage. and destruction of the Christians". The king's reaction was restrained. He ordered only a discreet investigation of the rumors. There survive neither responses to Fernando's queries nor record of the punishment of Mudejar subversives (10).

The rumors seem ridiculous. Certainly, with his hands full in the east and in Egypt, Bayezit was not in any position to mount an invasion of Spain and thereby lend substance to Mudejar plans. Nevertheless, this does not exonerate the Mudejars of the intention of rebellion under propitious circumstances. It is very much within the realm of possibility that Mudejar-Ottoman contact had, in fact, been established.

By 1487 Nașrid poetic appeals for assistance reached both Ottoman and Mamluk courts. Bayezit responded by sending the privateer Kemal Reis to the western Mediterranean on a reconaissance mission. Reis based himself as a corsair in Bougie and Bône and is thought to have made contact with Granadan Muslims somewhere along Spain's southeastern coast. The close ties between Valencian and Granadan Muslims, the great concern for Granada expressed in the Mudejars' alleged embass ${ }_{m}$ and the embassy's temporal conjunction with the Nașrid appeal lead to the conjecture that Mudejar envoys in the company of Granadan counterparts met not with Bayezit, but with Kemal Reis on either the Andalusian or the Maghriban coast (11). The Mudejars were certainly in touch with Ottoman corsairs by 1502 (12). Earlier contacts, while there was still some hope for the Nașrids, do not seem improbable. In any case, once Granada was conquered, the threat of an Ottoman invasion in relief of the Nașrids was removed, and with it the possibility of a large-scale Mudejar insurrection.

The initial years of Fernando's reign saw a continuation of Valencia's trade with Granada and the Maghrib, in which Mudejar merchants played an important role (13).

(10) ACA: C 3665: 72r (23 April, 1487): "E que axi matex havrien (the Muslim ajamas of the kingdom) elets e diputats dos moros per missatgers la hu de la moreria de Xativa el altre de la de Paterna apellat Pacoret e aquells havrien tramesos al Thurch per notificarli la guerra que per nos se fa al dit rey de Granada e la perdicio en que aquell ere si per lo dit Thurch no fos subvengut e ajudat, la qual ajuda havia esser tremetre ses gents en nostres regnes e signantment en lo dit regne de Valencia en lo qual e en los altres li no tificaven trabaria docents milia combatents moros qui de continent se levarian en sa ajuda e favor contra les crestians en deservey nostre e dan e destruccio dels crestians... vos... manam... que... reeban veridica informacio redigida en scrits de totes les damunt dites coses. e aquella closa segell orda e te fahent nos trametan perque vista puixam provehir sobre les dites coses degudament migançant justicia en castich e punitio de les dits moros e morerias juxta los crims excessos e delictes que contra aquells e aquelles legitimament se provarann.

(11) RACHEL ARIÉ, L'Espagne musulmane au temps des Nassrides (1232-1492) (Paris, 1973), pp. 172-174, discusses the Nasrid embassy to the Mamluk court; and ANDREW C. HESS, The Forgotten Frontier (Chicago, 1978), pp. 60-61, 228, treats the mission of Kemal Reis in response to the Naşrid appeal. On a later and more serious manifestation of the connection between Spanish Muslims and the Ottomans, see ANDREW HESS, wThe Moriscos. An Ottoman Fifth Column in Sixteenth Century Spainn, American Historical Reviuw, 74 (1969), pp. 1-25.

(12) See below, note 53 .

(13) HINOJOSA, "Relaciones", pp. 111-128, treats Valencia's commerce with Granada and Mudejar participation. For Fernando's reign, ARV: C 707: 789v-790r (17 May, 1479), and 889v-890r (30 June, 1481), are examples of liceses granted to Mudejars for travel to Almería for reasons of commerce. ARV: B 1157: $327 \mathrm{r}-\mathrm{V}$ (23 October, 1481 ); and AMV: $\mathrm{g}^{3}$ 29: $179 \mathrm{r}-180 \mathrm{R}$ (9 December, 1479), are examples of correspondence between Valencian and Granadan officials concerning the activities of Valencian merchants in Almería. JACQUELINE GUIRAL, "Les relations commerciales du rovaume de Valence avec la Berbérie au XV' sièclen, Mélanges de la Casa de Velázquez, 10 (1974), pp. 99-131. ARV: C 707: $791 v-793 r$ (19 January, 1480), and $912 \mathrm{r}-\mathrm{v}$ (24 November, 1484), are examples of licenses granted to Mudejars for travel to the Maghrib on commercial business. 
There also persisted the accustomed nuisance of Mudejar collusion with the Granadan "almugavers" and Maghriban corsairs who raided the kingdom in quest of booty and captives (14). In 1481, and again in 1483, Fernando deplored the fact that calmugavers" were secretly entering Valencia from Granada and perpetrating many crimes against the persons and property of Christians travelling on the kingdom's roads. The raiders were making themselves inconspicuous by mixing in the Mudejar morerias. As a remedy, the king commanded that all Muslims travelling by unaccustomed routes were to be seized and brought before the bailiff general for judgement. The guides, presumably Mudejars, captured in the company of enemy Muslims were to be punished in exemplary fashion (15). Entire morerias, the majority of whose inhabitants probably turned a blind eye to the comings and goings of the Granadan visitors, would, therefore, escape chastisement. The measure had some success. A few Mudejars were arrested for the crime of "collera" - the kidnapping of Christians for sale as slaves in Islamic countries (16) - , "almugavers" were captured (17), and Muslims travelling on prohibited backroads were apprehended (18). The depredations of the "almugavers" and their Mudejar colleagues ceased after 1483, when the escalation of the war against Granada forced the Nașrids into a defensive posture (19).

Mudejar travel to the Maghrib for purpose of trade and visiting kinfolk (20), and the presence in Valencia of Maghriban merchants (21) and Maghriban and Granadan

(14) JUAN TORRES FONTES, "La Hermandad de moros e cristianos para el rescate de cautivos", in Actas del / Simposio Internacional de Mudejarismo (Madrid-Teruel, 19811, 499-508, discusses this problem, and the appendix contains the text of an order of lsabel (21 May, 1483 ) demanding the punishment of Murcian Mudejars who protected Granadan raiders.

(15) ARV: B 1157: 119r-120r (15 September, 1481): a...considerat que de tots dies cometen molts e diversos dans per los camins del regne de Valencia en les per sones bens e mercaderies dels crestians vassalls e subdits nostres e altres passatgers... los quals son fets e perpetrats per alguns infeels e moros qui entren occultament e amagada de les parts e terres de Granada en lo dit nostre regne de Valencia en lo qual per les grans moreries quey son augmenter de numero de gent pera fer majors dans... en detriment... e evident dan de nostres subdits e vassalls crestians com los moros vagen segurs per lo dit regne sens esser los fet dan algu... ordenam ab la present provisio real... que tota hora e quant per qualsevol persones... seran presos qualsevol moros e les robes diners joyes entrant passant exint e tornant sen per lo dit nostre regne de nits o de dia per vies insolites e camins no acostumats que les persones e bens dels dits moros... sien portats davant lo nostre batle general... e que aquell sia tengut judicar aqueli ta. moro o moros, que si algu 0 alguns adelils seran presos en la dita companyia de moros que aquell o aquells sien donats... a nos e a nostres officials perque... justitia... sia administrada a castich de aquells e a example de les males gents...". ACA: C 3633: 117r-v 110 February, 1483 , is a reiteration of the above provision. Probably in relation to this problem was the royal proclamation made in 1481 that all Musfims and Jews must symbols wear distinguishing them from Christian. ARV: MR 92: 321r. In ACA: C 3665: 20v-21r ( 5 December, 1486). Fernando explicitly cites the Mudejars's failure to wear symbols as being a factor which enables them, incognito, to assault and kidnap Christians: a...se segueix que per no anar senyalats los dits moros ans vestits indifferentment com a crestians. e sens barbes ni toques ni altres senyals de moros se fan de totes dies de moltes insults e desordens cativant crestians e aquells injuriant e maltractant e jahent ab crestianes... H wowever, by 1486, Christian captives, if they were, in fact, taken, probably would have been handed over to Maghriban rather than to Granadan Muslims.

(16) ARV: C 126: 124r-v (3 March, 1480), and ARV: C 304: 71r-v (26 Mav, 1480), deal with cases of "collera", as does

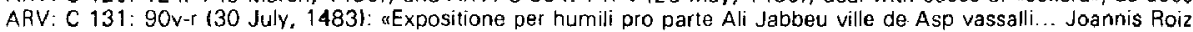
de Corella Comitis de Cocentayna Maiestati nostre facta precipimus quemadmodum his jam elapsis diebus ipse inculpatus delatus et accusatus fuit per Petrum Martinez Berganti procuratorem fisci nostri de crimine intercipiendi et captivandi christianos scilicet quod sarracenis qui ex sarracenorum terra videlicet ex Regno Granate in Regnum nostrum Valentie uti fieri solet venirint ut christianos captivos secum adducerat consilium auxilium et favorem dabet atque prestabat".

117) ACA: C 3605: 85v-86r 17 December, 1480), deals with the case of uaimugavers" captured in the lands of the infante Enrique, the Duke of Segorbe, although this was before Fernando's measures took effect. ACA: C 3605: 118r 128 September, 1481): "calmugavers" are captured in Murcia.

18) ARV: B 1157: 156r 17 January, 14821: Mudejars travelling on a prohibited route between Tibi and Cocentaina are apprehended.

(19) This is suggested by the absence of evidence of further aalmugaver" activity. ACA: C 3649: 150v-151v (6 April, 1492 ). shows how well the kingdom's roads were controlled. Murcian Muslims could enter the kingdom only through the city of Orihuela. Thus, once the war had ended, the lord of the Valle de Ricote in Murcia asked that these travel restrictions be lifted

(20) See note 13. ARV: C 707 also contains numerous examples of Mudejars travelling to the Maghrib on family business, such as 796v-797r (12 January, 1480), a license to Azmet Gallinavre of Oliva to travel to Tunis uper recaptar una herencia de hun parent seu que alli es mortn; or 914r-v 126 November, 1484), a license to Muhammad Perpir of Valencia to go to Tunis aper veure hun jerma de aquell que te en la dita ciutat e per haver una herencian.

(21) Guiral, "Relations commerciales", pp. 107-111. However, Guiral's article needs some correction. Her graph and tables, pp. 123-124, 131, suggest that there were not any Maghriban merchants in Valencia between 1493 and 1502 , when, in fact, the registers ARV: B 1160 (e. g., 915v-916r), B 1161 (e.g., 15v-16r), and B 1162 (e. g., 123v-124r) contain safe-conducts permitting one year of residence in the kingdom to Maghriban merchants. 
captives, some of whom, once ransomed, remained in Valencia (22), provided Maghriban corsairs with a potential network of spies and guides who could facilitate their infiltration of Valencian territory. Although Mudejar insurgence of this sort was by no means widespread, it was sufficiently vexatious to prompt the bailiff general to prohibit the ownership of fishing boats by Mudejars, so that they could not, under pretense of fishing, lead corsair galleys to Valencia's shores (23). Indeed, a Mudejar of Cocentaina was captured in the company of 100 raiders from Oran (24). Even more striking was the information that a Muslim from Oliva was piloting a corsair fleet (25).

The absence of energetic royal action to curb such Mudejar activity can in part be explained with one of the arguments of Valencia's nobles against the conversion of the Mudejars in 1502. They maintained that Mudejars often advised Christians of the coming of corsairs (26). In 1503, while requesting that their Muslim vassals who had fled to the Maghrib be allowed to return to Valencia, certain lords emphasized that while their vassals were in Africa they did not capture Christians, rather they picked up information regarding "...the damage that the Moors from beyond would like to do (27)». Fernando, impressed, complied. Thus, the intelligence network between Muslims of opposite Mediterranean shores could work both ways, sometimes to the kingdom's benefit.

The exigencies of the decade-long crusade against Granada did not drastically alter Fernando's Mudejar policy. Strategies were not adapted for the eventuality of a Mudejar rising in Granada's favor, nor were preventive measures taken beyond the investigation of rumors. The Mudejars were not significantly disturbed in their local economic and social pursuits. The only restrictions imposed were those limiting Mudejar travel to the regions of the kingdom closest to Granada and the passage of Muslims between Valencia and the Maghrib. So as not to curb Mudejar commercial activity any more than was absolutely necessary, the restrictions were relaxed in 1491 , when victory seemed at hand (28). The probable opposition of the nobility, capable of con-

(22) Vicenta Cortes, La esclavitud en Valencia durante el reinado de los Reyes Catolicos (1479-1516) Valencia, 1964), is a useful, though by no means exhaustive, treatment of the problem; and Guiral, "Relations commerciales", pp. 114-116. 126-129. Also, see below, note 38 .

(23) ARV: C 596: 147r-v (7 June, 1494); «En aquest vostre Regne de Valencia de alguns anys en ça se son seguits grans inconvenients a causa que los moros que stan en les viles e lochs maritims de aquest vostre Regne de Valencia tenen arcs e barques de peixcar ... e sots color de exercir la dita art de peixcar son receptats en aquest Regne per aquells moros stranys ab fustes pera cativar los crestians...n.

(24) ARV: C 311: 254v-255r (6 June, 1502): a ...vos diem façan del moro de Cocentayna que fonch pres en la dita cavalcada quis diu tenin en la presa en cas que per justitia no haja a esser condempnat a mort per esser de la terra e trobarse ab los enemichs.... ARV: B 195: 65r rv (30 April, 1502): a captured corsair from Oran confesses that his party was guided from Guardamar inland to Rojales by a Mudejar of Albatera.

(25) AMV: $g^{3} 33$ : 249r (2 April, 1501): "...en Ora an armat sis fustes ...e que venen per pilot de Bablaguer moro de Oliva,"

(26) ARV: C650: 243r (12 April, 1502): "...fins ara en aquest regne en to temps que los maros no tenien recel...de esser forçats...ferse crestians...quant fustes algunes de moros venien en aquest regne los moros del dit regne eren en avisa dels crestians com es vist per speriencia moltes vegades."

(27) ARV: B 1162: 428v-429r (1 April, 1503): “...nos ha seydo fecha relacion los dichos moros al tiempo que se fueron no se levaron cristianos algunos ante dende alla han dado algunos havises del danyo que los moros de alende querian fazer. E que voluntariamente se quieren volver a vivir a esse Reyno como solian....

(28) Leopoldo Piles, "La situación social de los moros de realengo en lá Valencia del siglo XV " Estudios de Historia Social de España, | (1949), p. 258, notes that it had been established by Alfonșo $V$ in 1418 that Muslims from areas north of the Jijona River could not travel south of the Jijona or to Castile with out the permission of the bailiff general. The registers ARV: B 1156-1162, contain licenses for travel beyond the Jijona. The number of licenses granted during the years of my study are as follows:

1496: 9 ( 2 may go to Granada)

1.497: 5

1498: 8 ( 8 may go to Granada) 
trolling their own Muslim vassals, and the size of the Muslim population dissuaded Fernando from an excessively repressive policy that might have provoked a rebellion more quickly than the war itself

In general, Fernando was confident that Christian dominance in Valencia would circumscribe Mudejar disloyalty to the few who intrigued with ualmugavers" and corsairs. Given the weakness of the Nașrids before the combined power of Castile and Aragon, he could afford to be somewhat lax. It is significant that he became wary of the Mudejars only with respect to the Turks, the one Islamic power with substantial offensive capabilities. The king's confidence was well-founded, for not a Mudejar sword was unsheathed in defense of the beleaguered Nasșrid sultanate.

Yet, it may be that the Mudejars were more willing to empty their purses in support of the Nașrids. In 1487 it was reported that they had been sending large annual subsidies to the sultan since 1481. The fuqahä' (alfaquis), who were responsible for collecting the funds, were also leading their congregations in a prayer that beseeched God to exalt the sultan and to destroy Fernando and his hosts. The king, exasperated, ordered investigation and, if necessary, punishment (29). Although the documents are otherwise silent on this matter, it seems reasonable that, in lieu of military activity, Valencia's Muslim minority would have resorted to financial aid and prayer on behalf of that remnant of al-Andalus to which they were bound by religion and kinship (30). Indeed, their effort to make contact with the Turks on the Nașrids' behalf, if true, is another indication of their deep attachment to the Granadan sultanate. Still, beyond the inaudible sinking of Muslim hearts, the fall of Granada had no further reverberations in Mudejar Valencia.

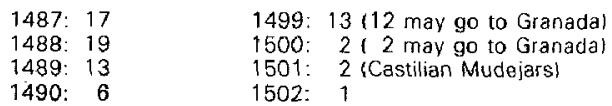

Taking in to accout economic fluctuations - since the majority of the Mudejars travelled south for commerce- I have at tributed the moderate decrease in the number of licenses granted from 1485 through 1490 to a more stringent wartime policy. The sharp increase in 1491 perhaps reflects a reaction to the relaxation of the previous stringency. The continuing high level in 1492 and 1493 can be attributed to post-war population shifts (Valencian Muslims retrieving relations for settlement in Valencia, ransomed slaves already residing in Valencia returning to Granada for personal business, and Valencia's Muslims taking advantage of the opportunity to visit Granadal, whereas the marked decrease after 1495 perhaps reflects a gradual cordoning off of the former sultanate as an aid to Talavera"s missionary efforts. The mere trickle from 1500 through 1502 was due to the revolts in the Alpujarras and the conversion of the Muslims of Granada, Murcia, and Castile.

Regarding the passage of Muslims between Valencia and the Maghrib, see note 21. Guiral's data, "Relations commerciales," pp. 123-124, 131, is accurate for the years before 1493. ARV: C 707 shows that between 1484 and 1491 there were no licenses for travel to the Maghrib granted to Mudejars. There was a very slight resumption of Mudejar travel in 1491: six licenses were granted, though three were to Castilians and one to an Aragonese Mudejar. Unfortunately, there are no registers following ARV: C 707, which terminates in 1491. Given the fact that Maghriban merchants continued to come to Valencia throughout the $1490 \mathrm{~s}$, even during the years of the crusade against Africa, there is no reason why Mudejars should not have resumed their visits to the Maghrib, particularly when one considers that the majority of the Mudejars had been travelling to Tunis, with which city Fernando maintained consistent commercial relations.

(29) ACA: C 3665: 20v-21r (5 December, 1486): Fernando mentions the report that the kingdom's morerias were sending the the sultan an annual subsidy of the value of the skins of the animals they had killed. ACA: C 3665: $72 \mathrm{r}$ (23 April. 1487) gives more detail: "Com siam informats que les aliames de moros de aquex nostre regne de $V a$ lencia axi de realench com altres axi aliamalment com singularment...de sis anys en ça havrien fets diversos socossos e subvencions de moltes quantitats de peccunia en grants sumes al rey de Granada... dipputant alfaquis e persones en cascuna aliama a plegar e rebre de cascun moro les dites subvencions e remetent les dites quantitats cascun any al dit rey perque de aquells fos ajudat en sa deffensio e contra aquesta sancta empresa ... encara los dits moros e los alfaquins de dites moreries del dit temps de aquesta empresa en ca havrien ordenada una certa oratio e aquella fan de continuu en ses ores contenent en effecte que Deu exalte lo dit rey de Granada e que destruesta a nos a totes nostres gents ab altres leges paraules de blasfemia que offenen les orelles." See note 10 for Fernando's order that these rumors be investigated.

(30) Hinojosa, "Relaciones," p. 104, suggest \$ that among Valencia's Mudejars the Nașrid sultan exercised "...una cierte jefatura, teorica al menos, en el campo espiritual...", emphasizing that in 1455 the sultan had expressed considerable anger to the jurats of Valencia over the attack on Valencia's moreria. One might also conjecture that Mudejars invoked the name of the reigning Naşrid in their Friday prayers. ARV: C 707, contains instances of Mudejars travelling to Almerfa on family business, such as Amet Biale of Castellnou, $786 \mathrm{v}-787 \mathrm{r}$ (12 May, 1479), or to study Arabic, such as Cahat Galip of Játiva, $820 \mathrm{r}-\mathrm{v}(19$ April, 1480$)$ 
Fernando's post-war policy was an expression of his belief in the continuing viability of Mudejarism. Satisfied that Valencia had survived the shocks of the Granadan campaigns and the worst of the Ottoman threat without major incident, he encouraged the settlement of Granadan Muslims in a number of Valencian localities (31). Also, he permitted Muslim travel from Valencia to the new kingdom of Granada (32). Unfortunately. Fernando's relatively "liberal" policy was to be thwarted by the extremism of Isabel and Cardinal Cisneros.

The Mudejars' quiescence during the war years can be explained by their awareness of the realities of power which neither the distant progress of the Turks nor the desultory raids of corsairs could change. The growth of Christian population in Valencia -approximately seventy per cent of the total by the mid-fifteenth century - and the increasing solidification of the structures of Christian authority brought home to the Mudejars the futility of rebellion (33). Moreover, the debility of the states of western Islam offered them little prospect of succor in the event of their rising (34). Only the Turks raised a faint glimmer of hope, but that quickly faded. Finally. more than two centuries of life under Christian rule had inured them to their subject status. The conditions which had made the Mudejar bristle in the thirteenth century were accepted with greater equanimity in the fifteenth.

This is not to suggest that the Mudejars were insensitive to the plight of their fellows. On the contrary, they displayed considerable commitment and sense of responsibility for their Muslim brethren, but they did so in areas where they could be most effective. Rather than making war, they aided prisoners of war; and rather than vainly rebelling against their Christian lords, they acted on behalf of the victims of oppression. Mudejars helped Muslim prisoners break out of seigneurial jails (35); they spirited away from brothels Muslim women forced into a life of prostitution (36); and at times they violently resisted the efforts of royal officials to punish members of their communities (37). Most impressive was Mudejar assistance to slaves and captives, which seems to have been organized among the kingdom's morerias. Runaways were hidden in the morerias and were given boats for escape to Africa. Captives were ransomed and then either sent home or welcomed as permanent community members (38). In this way the Mudejars met the claims made on them by membership in an

(31) Some examples are ARV: C 148: 214r-v (4 September, 1493): Fernando settles Muslims from the city of Granada on lands held by the bailiff general near Orihuela, and the new vassals swear to remain there for five years; ARV: 81160 . $18 \mathrm{v} 28 \mathrm{~J}$ anuary, 1491): Amir Alcaras from the Vall de Uxo travels to Almería in order to bring back his mother and sister for relocation in Valencia; and ARV: B 1159: $251 \mathrm{r}-252 \mathrm{r}$ (25 October, 14891. Muslims, originally of Vera, come fram Oran to speak with Fernando regarding the settlement in Valencia of others rom Vera, still in Oran

(32) ARV: B 1160: 646v-647r (26 March, 1493): Fotava Cot of the Vall de Uxo is granted license to go to Granada to study Islamic law. ARV: B 1160; $554 \mathrm{v}-555 \mathrm{r}$ (27 October, 1492): a family of ransomed slaves from Málaga is granted permission to return to Málaga to visit relatives; they are royal vassals and will be returning to Valencia.

(33) Regarding the change in the Muslim-Christian population ratio, I am, for the moment, following María del Carmen Barceió Torres, Minorias islámicas en el Pais Valenciano: Historia y Dialecto (Valencia, 1984), pp. 64-70. I have not yet drawn my own conclusions on this question, though I doubt that they will differ substantially from the $30: 70$ per cent ratio. Suffice it to say that the thirteenth century situation of Christians awash in a sea of Muslims had, by the mid-fifteenth century, reversed. The decreasing incidence of Mudejar rebellion parallels the increase in the Christian population

(34) Hess, op. cit., op. 11-25, contrasts the political and military weakness of the Islamic west with the strength and gunpowder technology of the unified Castile and Aragon. See also, Jamil M. Abun-Nasr, A History of the Maghrib $1 C a m b r i d g e$, 19751, pp. 119-166; and Arié, $o p$. cit., pp. 129-178.

135) ACA: C 3633: 79v-80r (25 February, 1479), and ARV: C 139: 72v-73v (19 May, 1495), discuss the attack of Muslims of Ressalany on Dos Aguas to free Muslims held prisoner there. ARV: C 148: 148v-149r (12 February, 1493 ): a Muslim is freed by coreligionists from the jail of the seigneur of Albatera.

(36) ARV: $81160: 17 \mathrm{~V} 125$ January, 14911 .

(37) For example, ARV: C 148: 142v-143v (25 January, 1493): the amin and jurats of Matet resist the efforts of the governor's officials to seize two Muslims who had fled from the place of Gaibiel.

138) One chapter of my doctoral dissertation will be devoted to the subject of Muslim slaves, both Valencian and foreign, and how the institution of slavery served, on the one hand, to define the inferior status of the Mudejar, and, on the other 
international Islamic community without rashly inciting the wrath of a king whose power they could not hope to challenge.

Despite all that has been said about the possibility of Mudejar disloyalty, one must not assume that all or even most of Fernando's Muslim subjects understood contemporary events in terms of Muslim-Christian confrontation, or that each one contemplated what might be done for the cause of Islam. Beneath all the crusading rhetoric lay the weighty determinant of self-interest. In a world where "realpolitik" was as important as ideology in the formation of alliances (39), where Granadan and Maghriban Muslims preferred to remain in Christian Valencia (40), and where Christians smuggled arms to Muslims and piloted their ships (41), it is no great wonder that most Mudejars were reluctant to risk physical security in Valencia in support of a divisive Maghrib or a declining Granada. Even within Valencia Muslims expended as much energy in internecine quarreling and family feuding as they did in cooperative defiance of Christian authority (42).

The rumblings of change and the origins of crisis for Valencia's Mudejars issued neither from the crusades against Islam nor from within Valencian society itself, but from Granada and Castile where Isabel and Cardinal Cisneros were eliminating Mudejarism. Cisneros' brand of conversion by coercion sparked Muslim revolts in the Albaicin and in the Alpujarras through 1500 and 1501 . Once the revolts were quelled Granada was completely "Christianized", and by February, 1502, Castile's Mudejars were offered the choice of baptism or expulsion (43).

If Fernando thought that his own kingdoms could remain immune to this tragedy of conflict and conversion, he was grievously mistaken. Certain elements of Valencia's Christian populace, who had abstained from anti-Mudejar violence despite the continual preaching of the crusade against Islam, began early in 1500 to murmur that Valencia's Muslims ought to convert, either voluntarily or by compulsion (44). These

hand, to strengthen the bonds of group solidarity within the Mudejar community and between that community and the wider Muslim world. Some pertinent documents are: ARV: B 1431: 374r (31 October, 1493): the bailiff general recognizes that the problem of runaway slaves is great owing to the aid the runaways receive from other Muslims; ARV: $C$ 650: $251 \mathrm{r}-253 \mathrm{r}(6 \mathrm{July}, 1502)$ : Fernando's lieutenant in the kingdom orders a general investigation of Mudejar assistance to runaways; ARV: $C$ 127: $125 \mathrm{v}(27 \mathrm{May}, 1480)$ : one of several ins tances in which a runaway disappeared in the morerias of the kingdom; ARV - $C$ 156: $200 r-v(19$ April, 1502): Muslims of Denia give to three runaways a boat and provisions to make their escape; ARV: B 219: 239r-240r (13 October, 1488): one of the more interesting of the numerous cases of Mudejars buying or ransoming captives, in which the aljama of Valencia purchases nineteen Malagan captives, all over sixty years of age; and ARV: B 1431: 344r-375r (1493): the case of a faqih from Tunis who remained in Ondara after having been ransomed by its aljama.

(39) This was long the case in the western Mediterranean. For instance, see Charlés Emmanuel Dufourcq, L'Espagne catalane ef le Maghrib au XIlle et XIVe siecles (Paris, 1966), and Abun-Nasr, op. cit., pp, 119-166. That it continued to be so is indicated by Fernando's alliance with the Mamluks against the Ottomans, and by the rerouteing of his African crusades toward Naples when it suited his interests. One important change was the union of Aragon and Castile, which rendered the Nastids incapable of playing off one Christian kingdom against the other.

(40) See notes 31 and 38 .

(41) This was another established Mediterranean practice. See Robert Ignatius Burns, "Renegades, Adventurers, and Sharp Businessmen; The Thirteenth Century Spaniard in the Cause of Islam," Catholic Historical Review, 57 (1972), $341-366$. ARV: B 1158: 73v (30 August, 1485): arms intended for illicit sale in the Maghrib are found on a Christian ship; and ARV: C 650: 253r-v \{18 July, 1502): Johan Andreu of biza is reported to be piloting a corsair fleet gathering in Bougie and Algiers.

142) Divisiveness within the Mudejar community is another theme I will treat in a separate chapter. It is abundantly clear from the documentation that the victims of Mudejar violence were most often Muslims, not Christians. One example is ARV: C 129: 142v-143v (13 September, 1481): Yũsuf Cabot, a royal vassal in Játiva, originaliy from Valldigna, returns to the valley and, with accomplices, murders a Muslim of Tavernes. The registers ARV: B $217+221$ contain official truces established between feuding Mudejars

(43) Miguel Ángel Ladero Quesada, Los Mudéjares de Castilla en tiempos de Isabel / Valladolid, 1969), pp. 69-82; and Hillgarth, op. cit., pp. $470-483$.

(44) AMV: $\mathrm{g}^{3}$ 33: $214 \mathrm{r}$ (29 February, 1500): the jurats of the city of Valencia inform Fernando of this problem. Regarding the question of popular Christian response to the preaching of the crusades in Valencia, although Fernando had to reprimand preachers in Zaragoza for inciting the populace against the Mudejars - ACA: C 3605: 136r (13 April, 1482), and ACA: C 3567: 152r 18 February, 1496) - this does not seem to have been a problem in Valencia. Only Maghriban merchants were assaulted, probably as a result of the preaching of the crusade against Africa, and royal proclamations against this were made in 1496 and 1497: ARV: MR 106: 245r (1496), and ARV: MR 107: $245 r$ (1497). 
rumor-mongers, approving of Cisneros' methods and perhaps frightened that Muslim rebellion would spread to their kingdom, threatened to foment a wave of anti-Muslim violence. Fernando responded quickly and placed all the morerías of the kingdom under special royal safeguard. He declared the principle that "...our holy Catholic faith in the conversion of the infidels admits neither violence nor any force but complete freedom and devotionn. Anyone daring to say the contrary or to inflict physical or verbal abuse on the Muslims was to be punished (45). The king had to issue the same order for Catalonia (46), and again for Valencia in 1502 (47).

In April, 1502, the nobles of Valencia informed Fernando that the Mudejars were gripped by two great fears: that they would be forced to convert or emigrate as were their coreligionists in Castile; and that the Inquisition was going to proceed against them for dissuading their fellows from baptism and for maintaining that Islam was a better religion (48). Having already admonished the Inquisitors, the nobles reminded Fernando that the Mudejars were the economic foundation of the kingdom without whom it would crumble. Already the distraught Muslims had stopped working and paying their rents. Instead, they were selling their property and hiding their goods in mountain caches. Those who had access to boats were leaving the kingdom (49).

Worse still, the Mudejars were being driven to the brink of violence. The nobles warned that there were more than 22,000 households of Muslims who were well armed, had an intelligence network, and lived near impregnable mountain fastnesses. An imprudent move on the king's part could result in the deaths of Christians

(45) ACA: C 3655: 34r-v (5 March, 1500): «A nostra noticia es pervengut que algunes malivoles persones les quals no mogudes per zel de la honor de nostre Senyor Deu no de la religio christiana mas per algunes sinestres e graves intencions han seminat en los pobles de aquex Regne que seria es es nostra intencio e voluntat per força reduyr a la sancta fe e religio christiana tots los moros del dit Regne e encara sembrant altres coses preparades a grans scandals per moure los pobles contra los dits moros e cercar ocasions de alvolotar e levarse contra ells, los quals tement aquestes novitats . los dits moros se retrahen de no exir de ses poblacions ni de negociar ni comerciar segons accostumaven per no esser dampnificats en llurs persones e bens. Les quals coses son...tant contraries a nostra intencio e voluntat com la nostra sancta fe catholica en la conversio dels infęels no admeta violencia ni força alguna sino summa libertat e devocio. $E$ per co declarant vos la intencio e voluntat nostra e volents que los qui tal dien sien castigats e punits e que los dits moros sien preservats...prenem e posam en nostra protectio e salvaguarda real totes les moreries... del dit nostre Regne e tots los poblats e habitants en aquelles... e que nengunes persones.. no gosen ni presumesquen no attenten de maltractar de fet ni de paraules als dits moros... ni parlar de la conversio de aquels ni ferlos dany en lfurs persones ni bens... E si per algu $o$ alguns ab osadia temeraria los sera feta o dita injuria alguna de fet o de paraula...ultra les penes que per furs del dit nostre Regne de Valencia...incorreguen en totes aquelles qui son introduydes e disposades contra los qui rompen nostra salvaguarda real...) ACA: C $3614: 53 \mathrm{v}-54$ r (26 March, 1500): Fernando assures the Intante Enrique that the rumors are false and that no action will be taken against the Mudejars.

(46) ACA: C 3600: $176 \mathrm{~V}-177 \mathrm{r}$ (30: September, 1501)

(47) ACA: C 3600: 191v-192r 20 February, 1502). Emilia Salvador, eSobre la emigración mudejar a Berberia. El tránsito legal a través del puerto de Valencia durante el primer cuarto del siglo XVI," Estudis, 4 (1975). pp. 61-63, transcribes this document, which is a reiteration of the order of 5 March, 1500.

(48) ARV: C 650: 240v-242r (12 April, 1502): "..dues coses que han granment en los animos dels dits moros augmentat la pahor que aquells temen la qual james han deposada per nengunes provisions que per vostra Alteza sien stades fetes La primera la crida que per manament de vostra Alteza es stada publicada en aquex Regne de Castella que los moros diris cert temps se haien a fer crestians o haien a buydar lo Regne... La segona quels es stat per suadit a donat a entendre jatsia fałsament que los Reverents Inquisidors de la heretica pravitat volen inquirir e procehir contra los moros de aquest Regne... La qual cosa ha causat en l'animo de aquells tan gran spant que tots stan fora de si matexes perque dien que de aço negu dells sen pot scusar perque publicament han tengut e tenen en lo present Regne ses mezquites e sos alfaquins los quals publicament los presiguen que la secta de Mahomat es millor que no la ley dels crestians...e que de aço...que se ha de seguir que ells per força se haien a fer crestians o que sen hagen a logir e anar tots del present Regne... E finalment nos ha paregut a tots que deviem los persones que som stades eletes per los dits Staments (military and ecclesiasticalt parlar als Reverents inquisidors... notificantlos que circa aquest negosi sabiem... dels receis que los moros temen e del gran dan que los crestians de aquest Regne porien rebre moventse algu avolot entre los dits maros... Nos han respost que la intencio dells no es lo que los dits moros se persuadexen.."

(49) ARV: C 650: 242r-v (12 April, 1502): “...aquest Regne ab inhicio es stat poblat ab aquestes heretats de moras e que tota la sustantia e patrimoni de les sglesies dels cavallers e dels ciutadans e altres habitants en lo dit Regne sta en lo fonament de aquestes poblacions de moros e en la conservacio de aquells. E que la poblacio de aquells es tan gran en aquest Regne que quaisevol destruccio o depopulacio ques seguexca en aquell es perpetualment destruhir aquest Regne...tots los moros de aquest Regne stan molt alterats e alborotats que no volen fer faena ne acudir a sos senyors a pagarles rendes com acostumaven e que tant com podem treballen en apartar sos bens en les montanyes e llochs hon tienen ells son forts en aquest Regne e en vend;e tot lo que poden... los que stan a la marina han furtades algunes barques. Les quals no sabiem... si ab dites barques sen son pasats alguns en terra de moros... 
and Muslims and in the destruction of much property (50). Fernando had to convince the Muslims that Castilian Mudejar policy would not have a Valencian sequel.

The king's initial response, an effort to freeze Mudejar movement, only caused more panic, since the Muslims saw this as a preliminary to their conversion (51). The untimely decision of Fernando's lieutenant to conduct an inquiry into the Mudejars' abetting of runaway slaves had a similar effect. Muslims continued to flock to Valencia's shores for escape (52).

During these panic-filled months of 1502 there came to the fore the Mudejars' contacts with Maghriban corsairs and their Ottoman allies (53). Muslim piratical activity noticeably increased in 1502 and 1503, as did the size and daring of their raiding parties (54). This was linked to peninsular events, since embittered Granadan Muslims had been filling the corsairs' ranks (55). It is clear that when corsairs set sail to plunder and terrorize Valencia's coasts they also had in mind assisting the kingdom's Muslims. Guided by Mudejar intelligence, the galleys arrived and picked up the Mudejars waiting on the shore (56).

It is significant that in this desperate situation the Mudejars chose flight instead of armed rebellion. On the one hand, it reflects the Mudejars' sense of impotence before Christian power in Valencia. On the other hand, the willingness to abandon

(50) ARV: C 650: 242v (12 April, 1502): “...e ques preparen e provehexen be armes a que tenen ses intelligencies los huns ab los aftres per hon sospitam que no tenen neguna bona intencio.. com hi haia pus de vint e dos milia cases de moros e que tenen moltes belies e forts places vent quels sia feta alguna força o violencia en compellirlas a fer crestians via directa o indirecta no façan algun moviment en aquest Regne que seria procurar algun irreparable dan. Car o seguint sen morts de crestians o destruccio de llurs o morts dels moros o destruccio de sos benes en totes maneres es dan pera aquest Regne irreparable.

(51) ARV: C 650: 247v-248r (24 May, 1502): "Car no obstant ques diga en la Real provisio que los moros no puguen desvasalfar dels senyors de qui son vasalls e ferse vasalls de altres ni puguen vendre los bens sehents e encara mobles que tenen ne per lo sembiant puixen tenir barques ni altres fustes pera pexcar ni entrar en la mar sots pena de cativs e altres penes. Encara que aquests remeys pareguen prima fas...profitosos e mostrants portar repos als dits moros empero nosaltres qui tenim clara noticia dels recels a temors que los dits moros tenen... entenem que los dits remeys . portarien augment dels recels que los dits moros tenen..."

(52) ARV: C 650, 251r-252y 16 July, 1502): "...a les portes de les mezquites dels dits lochs han afigit certs cartells ab los Quals citen e manen a les aljames e alamins velis e novells dels dits lochs que per tot lo propasat mes de Juny sien e compareguen en la present ciutat...per respondre davant la...Senyora Reyna (of Sicily, Fernando's lieutenant general in the kingdom) a qualsevol demandes axi civils com criminals... per raho de haver receptat e amagat catius... Lo que ha fet grandissima operacio en totes los poblacios dels dits moros perque los dits moros dien que aquest modo e forma de procehir nos fa sino a fi de voler los incudir temors dient que las aljamas han delinquit e que per rembre la punicio del crim quels es imposat los sera forçat o de ferse crestians o buydar los Regne...tan gran es la temor de aquells que los dits cartells hun dia de dijous foren afigits a les portes de la mezquita de hun Iloch appellat Altea terme de Calp que es del noble Don Palafoix de Reboltedo e lo.disapte apres seguent sen anaren tots los vasalls e habitants en lo dit loch moros los quats eren cent setanta. los quals sen son anats en dues fustes molt poques de Turchs... En apres de la fisyta de aquells se son fogits pus de vint e cinch vasalls de la baronia de Callosa..."

(53) That the Turks were also involved is indicated in note 52 - ufustes molt poques de Turchsn - and in the reports received by the jurats of Valencia from lbiza - AMV: $g^{3} 34: 4 v(3$ June, 1502), 10v-11r(16 July, 1502), and ARV: C 650: 253r-v (18 July, 1502) - which mention efustes de Turchs", as well as afustes de moros" gathering in Bougie and Algiers.

(54) AMV: $g^{3}$ 33: 290v-291r (1 May, 1502): in response to the increased piratical activity, the capital and the other coastal towns of the kingdom establish a warning system utilizing smoke signals to advise of the enemy's approach and the size of his forces. AMV: $\mathrm{g}^{3} 34: 171 \mathrm{r}-173 \mathrm{~F}$ (30 August, 1503): Cullera is sacked by a force of more than 600 corsairs and more than 200 Christian captives are taken. There were other attacks of lesser dimension, for example. ARV: C 311: $254 v-255 r(6 \mathrm{June}, 1502)$ : the town of Almoradi defends itself against more than 100 raiders from Oran and Tlemsen

(55) Fernand Braudel, "Les Espagnols et f'Afrique du Nord de 1492 a 1577, Revue Africaine, 69 (1928), pp. 203.208, sug gets that the crusade against Africa had as one of its motives the etimination of the activities of Maghriban corsairs among whom the refugees from Granada proved to be Spain's bitterest enemies. ARV: B 195: 65r-v (30 April, 1502 ) the testimony of a Granadan Muslim who became a corsair in Oran after residing in Paterna for some years.

(56) AMV: $g^{3} 34: 2 v 127$ May, 1502): «...fustes de moros venen a la vora de la mar al stany de Corbera e fan fochs...es gran dan de tota la costa per quant los moros de la costa se creu ques recullen e sen van en les dites fustes..." AMV. $\mathrm{g}^{3}$ 34: 11r(16 July, 1502): a... de continu arriben fustes de moros e ab la intelligencia que tenen de alguns moros del present regne que nos partexen de les marines sen parten molts moros de la Vall d'Altandech e del loch de Piles. . ARV: C 650: $253 \mathrm{r}-\mathrm{V}$ (18 July. 1502 R regarding the report that eighteen Maghriban and Turkish galleys were preparing to sail for Valencia, the nobles note. "... Ios moros de aquest Regne stan tant comoguts per llur temor de esser forçats de ferse crestians que tots se lexaron anar com a desesperats per recullirse en dites fustes. Maiorment que en aquest Regne es lo Vall de Guadalest e altres lochs per hon los moros poden arribar a mar sens empach algu e que se porien reculir ço que tenen ells be percebut e practicat.n 
their homes and possessions shows that for the Mudejars the freedom to practice Islam outweighed all other considerations. When forced to convert in 1525, a number of Mudejars would resort to armed resistance (57). When, in 1503, Fernando restored calm and assured all parties in the Corts of Barcelona that Islam would continue to be sanctioned by royal authority, a number of Mudejars returned home from the Maghrib (58). As long as they could practice Islam, Valencia's Muslims preferred to do so in Valencia.

In conclusion, the international clash between Christianity and Islam did not have in Valencia an impact sufficient to unravel the resilient fabric of Muslim-Christian "convivencian. The Mudejars did not express their identification with Islam by rebelling against their crusading king; nor did that king harshly oppress his Muslim subjects while warring with Islamic states. The occasional Mudejar collusion with Muslim enemies was borne as a customary feature of frontier life, an insignificant annoyance in comparison with the economic benefits accruing from the Mudejar presence. A key factor in explaining why Valencia's Christians and Muslims did not rise up in violence against each other in response to the promotion of crusade is that for them ChristianMuslim conflict, on either the local or the international scale, was not anything new. Ever-present in the social formula of "convivencia" itself was the element of ideological antagonism, which was either mitigated or aggravated by economic and social factors. Indeed, economic and social distress, the result of forces external to the fundamental religious difference, was usually most responsible for the eruption of violence (59). More novel than war with Islam was the harnessing of Aragon to the Castilian juggernaut, which, while it allowed for the final conquest of Granada, also unleashed forces within Valencia that threatened its tradition of Mudejarism. Although the union of the two Crowns set the stage for Spain's imperial achievements, it redirected the destinies of its constituent societies in sometimes tragic ways.

ABBREVIATIONS ACA: Archivo de la Corona de Aragón
ARV: Archivo del Reino de Valencia
AMV: Archivo Municipal de Valencia
C: Real Cancilleria
B: Bailia General
MR: Maestre Racional
$\mathrm{g}^{3}:$ Lletres Missives

1571 Ricardo García Cárcel, "La revuelta morisca de Espadán." Al-Andalus 119761, 121-146.

1581 See, for example, note 27

(59) The importance of economic and social factors in the generation of ant-Muslim violence can be seen in the atlack on the moreria of Valencia in 1455 which occurred during a time of plague, drought, and rising prices, and had as its leaders the urban unemployed and lower classes - and in the anti-Mudejat action of the Germanias in 1521 - which had as its prime victims the wealthier Mudejars of the irrigated huertas and occurred only after the Mudejars had fought in seigneurial armies against the Germanias. On 1455, see Hinojosa, "Relaciones," p. 103; Gual, "Mudéjares," pp 472-484; Leopoldo Piles Ros, Apuntes para la historia económico-social de Vatencia durante el siglo XV (valencia, 1969). pp. 115-119; and Ricardo Garcia Cárcel and E. Ciscar Pallarés, Moriscos ragermanats IValencia, 19741, p 30 On the Germanias, see Ricardo Garcia Cárcel, Las Germanias de Valencia \{Barcelona, 19811, pp. 186-191, and Garcia and Ciscar, oo crt. op. $121-130$

- The writer gratefully acknowledges the Comite Conjunto Hsspano-Nonteamericano for its funding of this project on Mus. ins and Mudejars in Eastern Spain. 